\title{
Trichostatin A and Zebularine along with E-cadherin re-expression enhance tumour necrosis factor-related apoptosis-inducing ligand (TRAIL)-mediated cell cycle arrest in human breast adenocarcinoma cells
}

\author{
Sonia How Ming Wong ${ }^{\mathrm{a}}$, Chee-Mun Fang ${ }^{\mathrm{b}}$, Hwei-San Loha ${ }^{\mathrm{a}}$, Siew Ching Ngai ${ }^{*}$ \\ ${ }^{a}$ School of Biosciences, Faculty of Science and Engineering, University of Nottingham Malaysia, 43500 Semenyih, Selangor, Malaysia \\ ${ }^{b}$ Division of Biomedical Sciences, School of Pharmacy, Faculty of Science and Engineering, University of Nottingham Malaysia, 43500 Semenyih, \\ Selangor, Malaysia
}

Received 30th September 2020 / Accepted 5th January 2021

\begin{abstract}
Breast cancer is the leading cause of death among women in which its definite cure remains uncovered. Tumour necrosis factor-related apoptosis inducing ligand (TRAIL) is a potential anti-cancer agent due to its selective killing towards cancer cells while sparing the healthy cells. However, it is limited by the development of TRAIL resistance. With the attempt to overcome TRAIL resistance, this research embarked to study the effect of epigenetic drugs, Trichostatin A (TSA) and Zebularine (Zeb) along with E-cadherin re-expression on anti-cancer effect in human breast adenocarcinoma cells. The MDA-MB-231 re-expressed with E-cadherin (231-EGFP) was treated with TSA and Zeb before being treated with TRAIL (TZT) to compare the effect on MDA-MB-231 and MCF-7. The cell viability, cell cycle and migration assays were conducted on these cells, prior to reverse-transcription-polymerase chain reaction (RT-PCR) targeted on proliferating cell nuclear antigen (PCNA), cyclin-dependent kinase 2 (CDK2), matrix metalloproteinase 9 (MMP9). TZT induced a significant increase in $\mathrm{G}_{0} / \mathrm{G}_{1}$-arrested cell population and reduction in cell viability in 231-EGFP. These were verified by the suppression of PCNA and CDK2 mRNA expression. However, there was a negligible effect to reduce the cell migration of the invasive MDA-MB-231 and 231-EGFP cells in accordance with the lack of down-regulation of MMP9. In conclusion, this research shows that TSA and Zeb have sensitized breast cancer towards TRAIL treatment in 231-EGFP cells, validating the potentiality of E-cadherin as a biomarker of TRAIL treatment efficacy in the invasive breast cancer.
\end{abstract}

Keywords: Breast cancer, cell cycle, resistance, TRAIL, Trichostatin A, Zebularine

\section{INTRODUCTION}

Breast cancer was a high mortality disease in Western countries with the current cancer incidence and mortality reduced (Leong et al., 2010; Azubuike et al., 2018). Lamentably, in recent years, breast cancer is assigned with the dreadful title as the most recurrent female malignancy in developing countries within the Asian region in place of the uterine cervix cancer (Agarwal et al., 2007). According to American Cancer Society Report (2020), it is expected that more than 1.8 million new cancer incidences are to be diagnosed in 2020 in the US. It is also expected that nearly

*Author for correspondence: Siew Ching Ngai, School of Biosciences, Faculty of Science and Engineering, University of Nottingham Malaysia, 43500 Semenyih, Selangor, Malaysia.

Email-Eunice.Ngai@nottingham.edu.my; eunice_ngai@yahoo.com 
one-half and over one-half of the cases and cancer deaths, respectively, will come from the Asian population (Bray et al., 2018) and the breast cancer incidence does not show a decreasing trend in the Asia-Pacific region (Youlden et al., 2014; Youlden et al., 2012; Shin et al., 2010). Despite advancements in early diagnosis and treatment have stabilized its incidence in the West (Kohler et al., 2015), the treatment of the less differentiated, more aggressive basal subtype triple negative breast cancer (TNBC) is to be uncovered as the respective targets, estrogen receptor (ER) and human epidermal growth factor receptor 2 (HER2) are not expressed in this subtypes for the established hormonal treatment (Scully et al., 2012), rendering the established targeted treatment ineffective.

As research is still actively ongoing to find a suitable targeted treatment for TNBC, patients diagnosed with TNBC are mostly left with the option of standard cytotoxic chemotherapy which is still met with varied responses between different TNBC molecular subtypes (Masuda et al., 2013). In this context, Tumour Necrosis Factor-related Apoptosis-inducing Ligand (TRAIL) is potentially to be the holy grail of the targeted cancer therapy in attribution to its selective induction of apoptosis in cancer cells, evading the non-malignant cells (Ashkenazi et al., 1999; Fulda, 2015). The recombinant human TRAIL (rhTRAIL) was proven as generally safe and well tolerated from Phase I human clinical trial on patients with advanced cancers (Herbst et al., 2010). The apoptosis signalling by TRAIL is triggered by its binding to the TRAIL receptor $1 / 2$ (TRAIL-R1/2) and inducing receptor oligomerization. This signal is transmitted through binding of the TRAIL-R1/2 cytoplasmic death domain to an adaptor domain called Fasassociated Death Domain (FADD) via homophilic interaction which associates with initiator procaspase- 8 and -10 to form the death inducing signalling complex (DISC). Ultimately, the apoptosis signal is transmitted to the apoptotic executioner caspases-3, -6, and -7 , resulting in the execution of apoptosis (Ashkenazi, 2008; Kelley and Ashkenazi, 2004).

Despite being such a promising anti-cancer drug, TRAIL, notwithstanding the extensive research being done on it, still has a far distance to travel from bench to bedside. This distance is largely bridged by various cancer cells having varied response to TRAIL-arbitrated apoptosis due to different intrinsic and acquired resistances being built up by cancer cells over the course of tumour evolution (Dimberg et al., 2013; Stuckey and Shah, 2013). For example, resistance can be developed via down-regulation of surface expression of TRAIL-R1 and-R2 and the TRAIL sensitivity could be restored after TRAIL-R1 and -R2 up-regulation in the human breast cancer cells (Di et al., 2013; Portanova et al., 2013; Yan et al., 2012). Despite MDA-MB-231 cells are TRAIL-sensitive (Butler et al., 2006; Zhang and Zhang, 2008), the surface expression of TRAIL$\mathrm{R} 1$ and $-\mathrm{R} 2$ can be reduced by TRAIL-induced endocytosis, thereby attenuating the TRAILstimulated apoptosis signal (Yoshida et al., 2009; Zhang et al., 2009).

Intriguingly, recently it was reported that the post-translational modifications of TRAIL death receptors, especially O-glycosylation of TRAIL$\mathrm{R} 1$ and $-\mathrm{R} 2$ are crucial determinants of receptors' membrane stability, clustering and subsequently DISC assembly followed by caspase- 8 activation (Twomey et al., 2015; Wagner et al., 2007). Besides, the deficiency of fucosylation has been reported to pave the way for TRAIL resistance, lead to evasion from natural killer cell-mediated tumor surveillance and ultimately cancer progression (Moriwaki et al., 2009). Therefore, it is hypothesized that TRAIL death-receptor-Oglycosylation is imperative for TRAIL-induced apoptosis signal transmission and the deficiency of which has evolved to be another adaptive defence of TRAIL resistance mechanism acquired during carcinogenesis.

These hindrances of TRAIL resistance have collectively pointed us to attempt on using the epigenetic drugs, Trichostatin A (TSA) and Zebularine (Zeb) as sensitizers to enhance TRAIL-induced apoptosis in MDA-MB-231, which is a TNBC cell. In this regard, positive response of enhanced TRAIL-induced apoptosis was reported in lung, pancreatic and colorectal cancer cells with higher expression of E-cadherin $(\mathrm{CDH} 1)$ as evidenced by augmented clustering of TRAIL receptors, assembly of DISC and activation of caspase-8 (Lu et al., 2014). Ecadherin, a cell adhesion protein, is a remarkable gene with dynamic expression during epithelialmesenchymal transition (EMT), a hallmark of 
cancer progression (van Roy and Berx, 2008). It is commonly believed that the loss of E-cadherin expression is due to the development of primary tumour cells into more invasive state via EMT (Bae et al., 2013; Onder et al., 2008; Shargh et al., 2014). However, mesenchymal-epithelial reverting transition (MerT) is also commonly witnessed in secondary metastatic site accompanied by re-expression of E-cadherin which facilitates intercellular adhesion for secondary tumour establishment (Chao et al., 2010; Kowalski et al., 2003). Therefore, our research aimed to investigate whether the dynamic expression of E-cadherin can serve as a biomarker of TRAIL treatment efficacy in breast cancer, just as its potential as a marker has been demonstrated in the aforementioned carcinomas.

On the other hand, a gamut of epigenetic drugs which alter gene expression at the level of chromatin architecture instead of genetic code have been revealed as favourable sensitizers of various cancers towards TRAIL treatment. For example, histone deacetylase inhibitor (HDACi) mediation improved TRAIL-induced apoptosis by inducing the expression of TRAIL-R2 in colon cancer (Kim et al., 2004) and by downregulating cellular FLICE-like inhibitory protein (c-FLIP), which is a caspase- 8 inhibitor in glioblastoma and breast cancer (Bangert et al., 2012; Lauricella et al., 2012). In addition, a group has also shown that the sequential treatment of breast carcinoma with HDACi, Trichostatin A (TSA), followed by TRAIL has enhanced the cellular surface expression of TRAIL-R1 and -R2 along with enhanced expression of the pro-apoptotic Bcl-2 family proteins (Singh et al., 2005). Apart from HDACi, DNA methyltransferase inhibitor (DNMTi), Zebularine, also displayed promising synergism with TRAIL potentially by increasing cellular fucosylation (Moriwaki et al., 2010).

In light of this, the anti-cancer efficacy of the proposed sequential treatment of TSA and Zeb followed by TRAIL (TZT) on E-cadherin reexpressed MDA-MB-231 (231-EGFP) alongside the potential of reducing the cell invasiveness were assessed at the cellular and molecular levels. The results from the cell viability assay, cell cycle distribution analysis and RT-PCR assessment of the cell cycle-regulated genes, are inclined to the positive potential of TSA and Zeb in sensitizing E-cadherin re-expressed MDA-MB-231 human breast adenocarcinoma towards an enhanced TRAIL anti-cancer efficacy. To the best of our knowledge, there has not been any research done on the potential synergism between the combined treatment of HDACi and DNMTi followed by TRAIL in the human breast carcinoma which makes the great value of this study stands out.

\section{MATERIALS AND METHODS}

\section{Cell culture maintenance}

The human breast adenocarcinoma MDA-MB231 and MCF-7 cell lines were cultured with Dulbecco's Modified Eagle Medium (DMEM) supplemented with $10 \%(\mathrm{v} / \mathrm{v})$ of fetal bovine serum and $1 \%(\mathrm{v} / \mathrm{v})$ penicillin-streptomycin and incubated at $37^{\circ} \mathrm{C}$ and $5 \% \quad \mathrm{CO}_{2}, \quad 95 \% \quad \mathrm{O}_{2}$ atmosphere. MCF-7 inherents E-cadherin expression while MDA-MB-231 lacks of Ecadherin expression (Lombaerts et al., 2006). MDA-MB-231 was transfected (steps as below) with pCDNA3.1(+) (\#2903) (231-EV) and Ecadherin-Green Fluorescent Protein (EGFP) plasmid, a gift from Jennifer Stow (Addgene plasmid \#28009) (231-EGFP), respectively, and maintained under the same condition with the addition of Geneticin (G418). The normal human breast epithelial MCF10A cell line was maintained with DMEM/F-12 supplemented with 5\% equine serum, $20 \mathrm{ng} / \mathrm{mL}$ epidermal growth factor, 0.5 $\mu \mathrm{g} / \mathrm{mL}$ hydrocortisone, $10 \mu \mathrm{g} / \mathrm{mL}$ insulin and $1 \%$ $(\mathrm{v} / \mathrm{v})$ penicillin-streptomycin at the same physical condition as above.

\section{Transfection of MDA-MB-231 with $E$ - cadherin-Green Fluorescent Protein (EGFP) plasmid}

MDA-MB-231 cells were seeded at $2.5 \times 10^{5}$ cells per well in a 6 -well plate. TransIT-X2 ${ }^{\circledR}$ Dynamic Delivery System (MIR 60004) was used to deliver the EGFP plasmid harbouring $C D H 1$ gene fused to the green fluorescent protein (CDH1-GFP) and the empty backbone vector, pCDNA3.1(+) (Thermo Fisher Scientific V79020) into MDAMB-231 respectively following the manufacturer's instructions. The cells were incubated for 24 and $48 \mathrm{~h}$. At $24 \mathrm{~h}$ post-transfection, $800 \mu \mathrm{g} / \mathrm{mL}$ G418 was added. On the $7^{\text {th }}$ day post-selection, the successful transfectants were continuously 
selected and expanded to form the cell lines of 231-EV and 231-EGFP. G418 selection on the indicated cell lines was maintained for 34 days before another round of transfection and selection process.

\section{Reverse transcription polymerase chain reaction (RT-PCR)}

The total RNA of MDA-MB-231, 231-EV and 231-EGFP was isolated at 24 and $48 \mathrm{~h}$ posttransfection by using RNeasy Plus Mini Kit (QIAGEN, NL) and treated with DNase I (Promega, U.S.A.). The first strand of cDNA was synthesised by using the Tetro cDNA Synthesis Kit (Bioline, U.S.A.). Subsequently, the synthesized first strand cDNA was subjected to PCR amplification by using the PCR reagents kit (Bioline, U.S.A.) targeting CDH1-GFP and betaactin housekeeping gene. The primer sequences are: CDH1-GFP, forward: 5'-GCTCCTGGAC GTAGCCT'TC-3'; reverse: 5'GAAAGCGGC TGATACTGACC-3' and beta-actin, forward: 5'AGAGCTACGAGCTGCCTGAC-3'; reverse: 5'-AGCACTGTGTTGGCGTACAG-3'. The PCR condition was $94^{\circ} \mathrm{C}$ for 2 min, 35 cycles of $94^{\circ} \mathrm{C}$ for $30 \mathrm{~s}, 55^{\circ} \mathrm{C}$ for $20 \mathrm{~s}$ and $72^{\circ} \mathrm{C}$ for $20 \mathrm{~s}$ followed by $72^{\circ} \mathrm{C}$ for $5 \mathrm{~min}$. The final PCR product was subjected to electrophoresis by using $1 \%$ agarose gel and visualized by SYBR ${ }^{\mathrm{TM}}$ Safe DNA Gel Stain (Thermo Fisher Scientific, USA).

\section{Flow cytometry and fluorescence microscopy of CDH1-GFP expression}

MDA-MB-231, 231-EV and 231-EGFP cells were harvested at 24 and $48 \mathrm{~h}$ post-transfection to make a cell suspension of $1 \times 10^{6}$ cells $/ \mathrm{mL}$. The cell suspension was then subjected to flow cytometric analysis of CDH1-GFP expression at the FL-1 channel gated for 12,000 events. MDAMB-231 and 231-EV were served as the control to gate off background fluorescence in this channel. Events collected above the background fluorescence were taken as successful transfectants of the EGFP plasmid. Besides, the cells were subjected to the FITC channel of Axio observer 7 inverted fluorescence microscopy (ZEISS, Germany).

\section{Cell viability assay}

MDA-MB-231, 231-EV, 231-EGFP, MCF-7 and MCF10A cells were seeded at $5 \times 10^{4}$ cells per well in 96-well plates. A total of four sub-toxic TZ concentrations, $\mathrm{IC}_{15}, \mathrm{IC}_{20}, \mathrm{IC}_{25}$ and $\mathrm{IC}_{30}$, were taken from the 3-(4,5-dimethylthiazol-2-yl)-2,5diphenyl tetrazolium bromide (MTT) survival curve of $M D A-M B-231$ which was treated with various combinations of TSA and Zeb (TZ) concentrations (Supplementary figure 1). The $\mathrm{IC}_{25}$ was chosen for TZT treatment because it gave the highest reduction of 231-EGFP cell viability as compared to $\mathrm{IC}_{15}, \mathrm{IC}_{20}$, and $\mathrm{IC}_{30}$ (Supplementary figure 2). At $24 \mathrm{~h}$ post-seeding, the cells were treated with (i) $\mathrm{IC}_{25}$ TSA (TSA), (ii) $\mathrm{IC}_{25} \mathrm{Zeb}$ (Zeb), (iii) $\mathrm{IC}_{25}$ TSA and Zeb (TZ), (iv) $50 \mathrm{ng} / \mathrm{mL}$ TRAIL (TRAIL) for $24 \mathrm{~h}$ and (v) TZ for $12 \mathrm{~h}$ followed by $50 \mathrm{ng} / \mathrm{mL}$ TRAIL for $24 \mathrm{~h}$ (TZT). The cells were added with $100 \mu \mathrm{L}$ MT'T solution (1 $\mathrm{mg} / \mathrm{mL}$ ) (Sigma-Aldrich, U.S.A.) after the removal of medium. After $4 \mathrm{~h}$ of incubation at $37^{\circ} \mathrm{C}$, the MT'T solution was removed and $150 \mu \mathrm{L}$ of dimethyl sulfoxide (DMSO) was added to dissolve the purple formazan crystals formed by MTT reduction. The net absorbance values were obtained by subtracting $\mathrm{A}_{630}$ from $\mathrm{A}_{570}$ and the survival fractions were calculated as the net absorbance in the treated cells over the net absorbance in the untreated control.

\section{Cell cycle analysis}

MDA-MB-231, 231-EV and 231-EGFP were seeded at $2.3 \times 10^{5}$ cells per well while MCF- 7 was seeded at $3.25 \times 10^{5}$ cells per well of 6 -well plate. At $24 \mathrm{~h}$ post-treatment, cells were harvested. Prechilled ethanol $(70 \% \mathrm{v} / \mathrm{v})$ was added at $500 \mu \mathrm{L}$ to the harvested cells prior to one week of cell fixing at $-20^{\circ} \mathrm{C}$. Subsequently, the cells were washed with cold $1 \times$ phosphate buffered saline (PBS) twice and pelleted via 5 min centrifugation at 2,000 rpm. After the supernatant has been removed, propidium iodide $(\mathrm{PI})$ staining solution of $1 \times \mathrm{PBS}$ dissolved with $0.1 \%$ (v/v) Triton X-100 (Nacalai Tesque, Japan), $50 \mu \mathrm{g} / \mathrm{mL}$ PI (Sigma-Aldrich, U.S.A.) and $100 \mu \mathrm{g} / \mathrm{mL}$ DNase-free RNase A (Nacalai Tesque, Japan) was added at $500 \mu \mathrm{L}$ to stain the cellular DNA. After $30 \mathrm{~min}$ of incubation at room temperature, the cellular DNA content was subjected to flow cytometry (BD Biosciences, U.S.A.) with 10,000 events recorded per sample. The percentage distribution of cells across the cell cycle phases of $G_{0} / G_{1}, S$ and $G_{2} / M$ was quantified using the ModFit $L^{T}{ }^{T M}$ software (Verity Software House, U.S.A.). 


\section{Cell migration assay}

MDA-MB-231, 231-EV, and 231-EGFP were seeded at $1 \times 10^{5}$ cells per well of 24 -well plates. Thereafter, the cell monolayer was wounded with a p200 tip at consistent pressure and pipette tip angle to keep the wound consistent (Jonkman et al., 2014). The wound was rinsed with $1 \times$ PBS before the addition of the different treatment regimens as aforementioned. The cell images were captured at $0,3,6,12$ and $24 \mathrm{~h}$ post-treatment. The area of the gap formed by the scratch was quantified using the ImageJ software with standard size criteria (Jonkman et al., 2014). The percentage of gap closure was determined based on the area of gap at time $0 \mathrm{~h}$ whereby higher percentage of gap closure signifies higher cellular invasiveness.

\section{RT-PCR assessment of proliferating cell nuclear antigen (PCNA), cyclin-dependent kinase-2 (CDK2) and matrix metalloproteinase 9 (MMP9)}

At $24 \mathrm{~h}$ post-treatment, the total RNA of MDAMB-231, 231-EGFP and MCF-7 was isolated and subjected to RT-PCR targeting proliferating cell nuclear antigen (PCNA), cyclin-dependent kinase-2 (CDK2), matrix metalloproteinase 9 (MMP9) and beta-actin housekeeping gene (sequence as indicated above). The primer sequences are as followed: PCNA, forward: 5'CCATCCTCAAGAAGGTGTTGG-3' and reverse: 5'-GTGTCCCATATCCGCAATTT'T AT-3'; CDK2, forward: 5'-CATGAGGTGGTG ACCCTGTG-3' and reverse: 5'-CAAATAGC CCAAGGCCAAGC-3'; MMP9, forward: 5'GATGCGTGGAGAGTCGAAAT-3' and reverse: 5'-CACCAAACTGGATGACGATG-3'. The PCR conditions were $94^{\circ} \mathrm{C}$ for $2 \mathrm{~min}, 35$ cycles of $94^{\circ} \mathrm{C}$ for $30 \mathrm{~s}, 55^{\circ} \mathrm{C}$ for $20 \mathrm{~s}$ and $72^{\circ} \mathrm{C}$ for $20 \mathrm{~s}$ followed by $72^{\circ} \mathrm{C}$ for $5 \mathrm{~min}$. The final PCR product was subjected to electrophoresis by using 1\% agarose gel and visualized by $\mathrm{SyBr}$ safe staining. The mRNA expression was calculated with the formula:

mRNA expression of the target gene $=$ Target gene band intensity/Beta-actin gene band intensity

\section{Statistical analysis}

The mean differences of cell viability percentage, cell proliferation rate, cell cycle phase's percentage distribution and percentage of gap closure (cell migration assay) were statistically analyzed using the IBM SPSS V.25. One-way ANOVA with Tukey post-hoc test was used in cell viability assay, cell cycle analysis and cell migration assay to determine the significant differences between the treated and the untreated control. The data presented were means \pm standard error mean $($ SEM). The statistical differences at $(\mathrm{P}<0.05)$ and $(\mathrm{P}<0.001)$ reflect significant and very significant, respectively.

\section{RESULTS}

\section{Successful expression of CDH1-GFP in the transfected MDA-MB-231}

MDA-MB-231 cells express none or low Ecadherin expression due to the dynamic and reversible $\mathrm{CDH} 1$ promoter methylation (Lombaerts et al., 2006). Figure 1A shows that EGFP plasmid has been successfully transfected into MDA-MB-231 and CDH1-GFP mRNA was expressed at the expected band size of $491 \mathrm{bp}$. The mRNA expression of CDH1-GFP was confirmed in 231-EGFP at $24 \mathrm{~h}$ and $48 \mathrm{~h}$ posttransfection (Figure 1A). Besides, the expression of CDH1-GFP at the protein level was also verified by flow cytometry. The successful transfection rate of 231-EGFP was $7.6 \%$ and $5.4 \%$ of the total cell population at 24 and $48 \mathrm{~h}$ post-transfection, respectively (Figure 1B). Throughout the course of G418 selection, fluorescence images captured using the FITC channel of Axio observer 7 inverted fluorescence microscope depicted a non-homogeneous expression of E-cadherin from EGFP plasmid in 231-EGFP while the MDA-MB-231 and 231-EV showed no GFP fluorescence (Figure 1C).

TSA and Zeb sensitization enhances TRAILinduced cytotoxicity in 231-EGFP while having no significant inhibitory effect on MCF10A

The combination of TSA and Zeb (TZ) was used to sensitize MDA-MB-231, 231-EV, 231-EGFP 
and MCF-7 in the TRAIL treatment. As shown in Figure 2, the reduction of cell viability induced by TSA, Zeb, TZ, TRAIL and TZT in MDA-MB231 and 231-EV was not significant compared to the untreated control. For MDA-MB-231 treated with TRAIL and TZT, the cell viability was reduced to $83.1 \%$ and $85.1 \%$, respectively at $24 \mathrm{~h}$, despite insignificant $(\mathrm{P}>0.05)$. For the $231-\mathrm{EV}$ which served as a control cell, the cell viability was insignificantly $(\mathrm{P}>0.05)$ reduced to $93.3 \%$ for the cells treated with TZT for $24 \mathrm{~h}$. Nonetheless, with the re-expression of E-cadherin, 231-EGFP has significantly $(\mathrm{P}<0.05)$ reduced cell viability to $70.3 \%$ and $79 \%$ after TZ and TRAIL treatment for $24 \mathrm{~h}$, respectively. Furthermore, with the consecutive treatment of TSA and Zeb combination followed by TRAIL (TZT), the cell viability was further reduced to $62.12 \%$ $(\mathrm{P}<0.001)$. Despite being statistically nonsignificant, TZT-treated MCF-7 has a reduced cell viability of $66.13 \%$ which is similar to TZTtreated 231-EGFP which has a cell viability of $62.12 \%$ (Figure 2). In the normal human breast epithelial MCF10A cell line treated with TZT, although the cell viability was significantly $(\mathrm{P}<0.05)$ reduced to $71 \%$ in comparison to the untreated cells, TZT treatment did not induce significant cytotoxicity in comparison to the other treatment regimens (Supplementary figure 3).
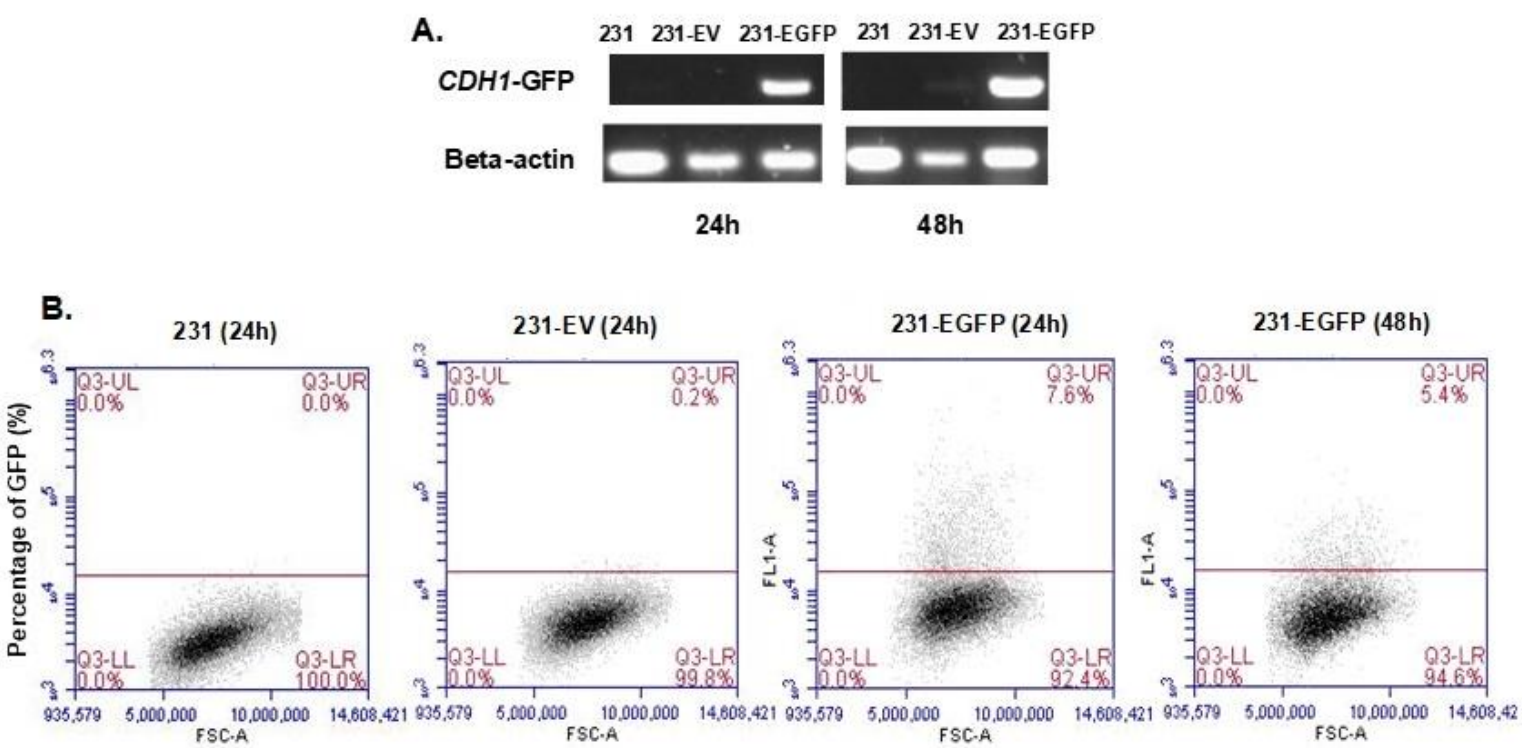

c.

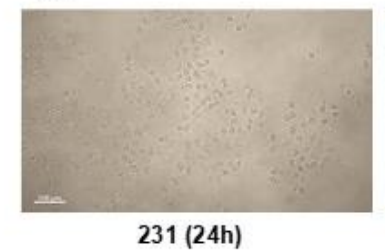

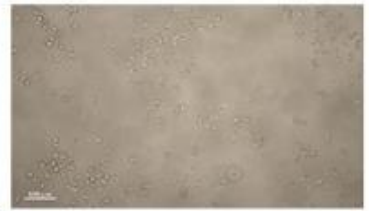

231-EV (24h)

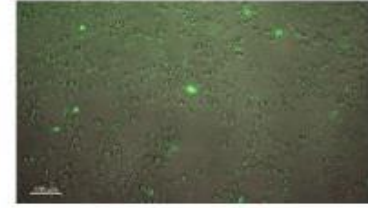

231-EGFP (24h)

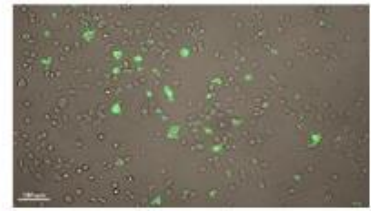

231-EGFP (48h)

Figure 1. Verification of mRNA and protein expression of CDH1-GFP in transfected MDA-MB-231. (A) Total RNA was extracted from MDA-MB-231 (231), MDA-MB-231 transfected with pCDNA3.1 (231-EV) and MDA-MB-231 transfected with EGFP plasmid (231-EGFP) for 24 and $48 \mathrm{~h}$, converted to cDNA and amplified by PCR using primers targeting CDH1-GFP (491 bp) and beta-actin housekeeping gene (182 bp). (B) The 231, 231-EV and 231-EGFP cells were subjected to flow cytometric analysis of GFP fluorescence on BD Accuri C6 flow cytometer (BD Biosciences, U.S.A.). (C) The 231, 231-EV and 231-EGFP cells were captured for green fluorescent protein GFP fluorescence under the bright field and FITC channel of Axio observer 7 inverted fluorescence microscope (ZEISS, Germany) at the 24 and 48 $\mathrm{h}$ post-transfection. Images shown are merged from the bright and FITC channel fields. Scale bars represent $100 \mu \mathrm{m}$. 


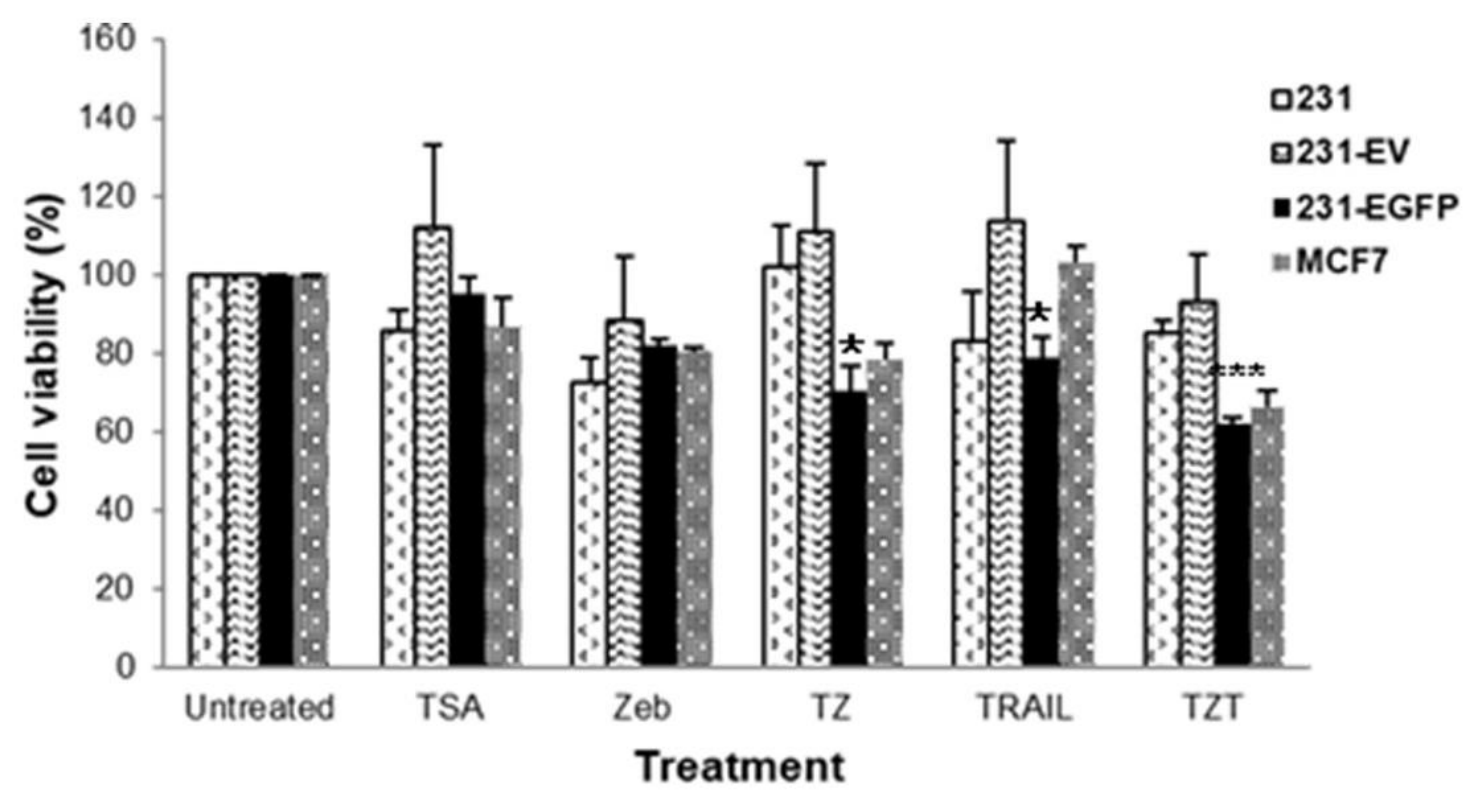

Figure 2. MTT cell viability data of MDA-MB-231 (231), geneticin selected MDA-MB-231 transfected with pCDNA3.1 empty vector (231-EV), and geneticin selected MDA-MB-231 transfected with Ecadherin-GFP plasmid (231-EGFP) and MCF-7 at $24 \mathrm{~h}$ post-treatment. All means are average of triplicate values from three independent experiments. Error bars represent SEM. One-Way ANOVA test was used to compare means of the different treatment groups. $*(\mathrm{P}<0.05)$ and $* * *(\mathrm{P}<0.001)$ represent significant and very significant differences from the untreated control.

TSA and Zeb sensitization increases TRAILinduced cell cycle phase $G_{0} / G_{1}$ arrest in $M D A-M B-231,231-E G F P$ and MCF-7

The favourable inhibition of 231-EGFP cell viability achieved by TZT treatment has guided us to further analyse its anti-cancer effect in the aspect of cell cycle distribution. TZT treatment showed that $57.8 \%$ of MDA-MB-231 cells were arrested very significantly $(\mathrm{P}<0.001)$ at $\mathrm{G}_{0} / \mathrm{G}_{1}$ phase. TSA arrested $41.8 \%(\mathrm{P}<0.05)$ while $\mathrm{TZ}$ arrested $43.2 \% \quad(\mathrm{P}<0.05)$ of MDA-MB-231at $\mathrm{G}_{0} / \mathrm{G}_{1}$ phase (Figure 3). Interestingly, TRAIL treatment has induced a significant $(\mathrm{P}<0.05) \mathrm{S}$ phase arrest at $56.2 \%$ (Supplementary figure 4) with no $G_{0} / G_{1}$ arrest (Figure 3) for $24 \mathrm{~h}$ treatment. In addition, TZT treatment also significantly arrested $66.3 \%(\mathrm{P}<0.05)$ of $231-\mathrm{EV}$ at $G_{0} / G_{1}$ phase compared to TRAIL alone treatment at $24 \mathrm{~h}$, having similar trend with MDAMB-231 (Figure 3). For 231-EGFP, a significant $74.2 \%(\mathrm{P}<0.05)$ arrest of 231-EGFP at $\mathrm{G}_{\mathrm{o}} / \mathrm{G}_{1}$ phase has been achieved by the TZT treatment (Figure 3), despite the induction of $\mathrm{G}_{0} / \mathrm{G}_{1}$ arrest by the other treatment regimens was insignificant. With regards to MCF-7 which inherently expresses E-cadherin, both TZ and TZT have significantly $(\mathrm{P}<0.05)$ arrested $82 \%$ and $83.1 \%$ of MCF-7 cells at $G_{0} / G_{1}$ phase while TRAIL alone did not increase the $G_{0} / G_{1}$ arrest appreciably from the untreated control (Figure 3).

\section{TZT treatment has a little effect in migration reduction of MDA-MB-231 and 231-EGFP}

There was one scientific report that shows TRAIL suppressing CXC chemokine receptor 4 (CXCR4)-cell migration in MDA-MB-231 (Wang et al., 2013) albeit the numerous findings that support the pro-invasiveness role of TRAIL (Wang et al., 2014; Fritsche et al., 2015). MDAMB-231 is highly invasive and migratory while MCF-7 is mostly poorly invasive in vitro (PerrotApplanat and Di Benedetto, 2012) due to the low vascular endothelial growth factor (VEGF) expression (Comsa et al., 2015). Therefore, it is justifiable to explore the effect of TRAIL and TZT treatment, with or without E-cadherin reexpression, on MDA-MB-231, 231-EV and 231EGFP.

Based on the results from the cell migration assay shown in Figure 4A, all treatment groups did not reduce MDA-MB-231 cell migration significantly except for the TZ treatment group. 
TZ has reduced the cell migration rate of MDAMB-231 significantly $(\mathrm{P}<0.05)$ to $7.1 \%, 14.9 \%$, $29.4 \%$ and $60.7 \%$ respectively at 3, 6, 12 and $24 \mathrm{~h}$ as compared to the untreated control with $21.2 \%$, $34.8 \%, 57.9 \%$ and $96.5 \%$ at the respective time point (Figure 4A). For 231-EV, the cell migration rate was significantly $(\mathrm{P}<0.05)$ reduced for $\mathrm{TZ}$ and TZT treatments at 3,6 and $12 \mathrm{~h}$ posttreatment. Nonetheless, TRAIL treatment only reduced the cell migration of 231-EV significantly $(\mathrm{P}<0.05)$ to $17.4 \%$ and $32.4 \%$ compared to untreated cells with $24.9 \%$ and $44.4 \%$ at 3 and 6 h post-treatment, respectively (Figure 4B). On the other hand, in 231-EGFP, Zeb significantly $(\mathrm{P}<0.05)$ reduced its cell migration rate at 6,12 and $24 \mathrm{~h}$ post-treatment. TZ treatment also significantly reduced $(\mathrm{P}<0.05)$ the cell migration rate at 6 and $12 \mathrm{~h}$ post-treatment but the reduction is very significant $(\mathrm{P}<0.001)$ to $80.7 \%$ at $24 \mathrm{~h}$ post-treatment compared to untreated control with migration rate of $100 \%$ (Figure 4C).

\section{TZT largely downregulates $P C N A$ and $C D K 2$ $m R N A$ expression in $M D A-M B-231,231-$ EGFP and MCF-7}

Based on the findings from the cell viability and cell cycle analyses above, there was cell growth inhibition and $G_{0} / G_{1}$ arrest induction in a significant percentage of cell population of MDAMB-231, 231-EGFP and MCF-7 treated with TZT. This has enticed our interest to elucidate its underlying molecular mechanisms. Previous report has stated that histone deacetylase inhibitor, MS-275, along with TRAIL have inhibited breast tumour cell proliferation in line with the reduction of proliferating cell nuclear antigen (PCNA) immunoreactivity (Srivastava et al., 2010). In addition, an important positive regulator of $\mathrm{G}_{1}-\mathrm{S}$ progression, cyclin-dependent kinase 2 (CDK2) (Sweeney et al., 1997), was downregulated by Zeb (Nakamura et al., 2013).

From the RT-PCR findings, there was PCNA upregulation of 7- and 4-fold in MDA-MB-231 with 24 hours treatment of TZ and TRAIL, respectively, as compared to that of the untreated control (PCNA relative intensity/ $\beta$-actin with value of 0.03 ) (Figure $5 \mathrm{~A}$ ). However, Zeb and TSA largely suppressed PCNA expression to 0.08 and 0.06, respectively. In 231-EGFP, Zeb and TZT have largely suppressed PCNA expression to 0.003 and 0.019 , respectively in comparison with 0.86 in the untreated control (Figure 5A). Nonetheless, in MCF-7, Zeb only induced approximately 2-fold downregulation of PCNA while TZT has downregulated PCNA expression to 19-fold lower than the untreated control (1.077) (Figure 5A).

On the other hand, both TSA, TZ and TRAIL treatments induced upregulation of CDK2 in MDA-MB-231 while Zeb and TZT treatments maintained low expression of CDK2, with the lowest expression given by Zeb (0.005) (Figure $5 \mathrm{~A})$. In 231-EGFP, all treatment groups have downregulated CDK2 while CDK2 was completely and largely suppressed by Zeb and TZT, respectively. Interestingly, all treatment groups have upregulated CDK2 in MCF-7 but TZT maintained the lowest CDK2 expression at 0.05 among all (Figure 5A). These findings are in line with the findings of cell cycle analysis (Figure 3) showing TZT is an effective treatment in arresting MDA-MB-231, 231-EGFP and MCF-7 at $\mathrm{G}_{0} / \mathrm{G}_{1}$ compared to the other treatment regimens.

\section{TZT treatment has an insignificant effect on the MMP9 downregulation in MDA-MB-231 and 231-EGFP}

Matrix metalloproteinase 9 (MMP9) is expressed significantly higher in MDA-MB-231 than in human normal breast epithelial HS578Bs cells and is associated with breast cancer metastasis ( $\mathrm{Li}$ et al., 2017). The expression of MMP9 was not suppressed in both MDA-MB-231 and 231EGFP treated with TZT (Figure 5B). For the MDA-MB-231 cells, the expression of MMP9 was not suppressed in all treatment regimens compared to the untreated cells. For the 231EGFP treated with Zeb, the expression of MMP9 was reduced to almost 4-fold lower (Figure 5B), which corroborates the findings from the cell migration assay reported above, in which the cell migration rate was reduced significant $(\mathrm{P}<0.05)$ to $89.1 \%$, compared to the untreated cells with $100 \%$ of migration rate (Figure 4). 


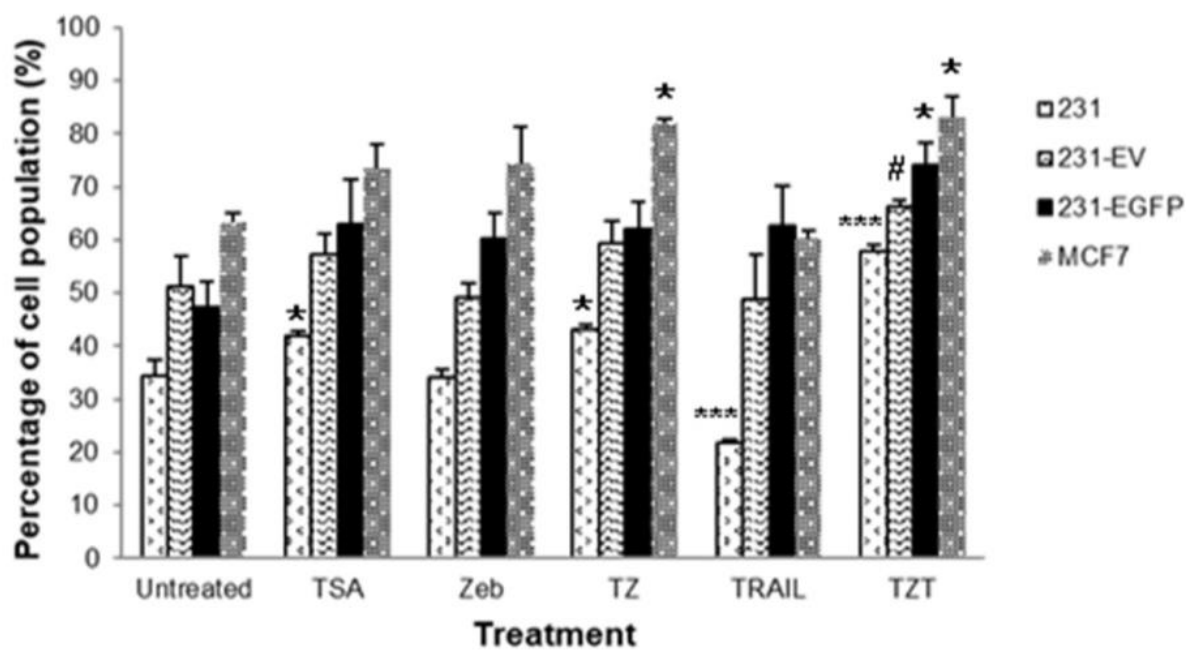

Figure 3. Percentage of cell population arrested at $G_{0} / G_{1}$ phase from cell cycle analysis of different treatment groups on MDA-MB-231 (231), 231-EV, 231-EGFP and MCF-7 at 24 h post-treatment. Data represents means + SEM of two independent experiments of duplicates. One-way ANOVA test was used to compare the statistical significance of means of cell population arrested at the $G_{0} / G_{1}$ cell cycle phase. $*(\mathrm{P}<0.05)$ and $* * *(\mathrm{P}<0.001)$ represent significant and very significant differences from the untreated group and all the other treatment groups, respectively. ${ }^{\#} \mathrm{P}<0.05$ is significant difference from the treatment, TRAIL.

\section{DISCUSSION}

In this report, the research work focuses on the effect of TSA and Zeb sensitization, with and without the re-expression of E-cadherin, on TRAIL-induced cell growth inhibition of human breast adenocarcinoma MDA-MB-231 cells. MCF-7 which inherently expresses E-cadherin was tested alongside to compare the treatment effects on both $\mathrm{CDH} 1$ transfected and nontransfected MDA-MB-231 cells.

The TZT treatment worked optimally at the time point of $24 \mathrm{~h}$. However, this is only the case for the E-cadherin re-expressed 231-EGFP and MCF-7 as for the MDA-MB-231 and 231-EV treated with TZT, there was no significant cell viability reduction. The nominal effect of the TZT treatment on MDA-MB-231 cells can be supported by the literatures on how the MDAMB-231, an initially TRAIL-sensitive cell can develop resistance towards sub-toxic doses of TRAIL via the endocytosis of its TRAIL-ligated cell surface receptors, TRAIL-R1 and TRAIL-R2 (Yoshida et al., 2009; Zhang et al., 2009). The internalization of TRAIL-R1 and TRAIL-R2 via the TRAIL ligation-induced endocytosis leads to dampening of the transmitted apoptosis signal, resulting in abated sensitivity of MDA-MB-231 towards TRAIL-induced apoptosis. Besides, a recent study in TRAIL-resistant breast cancer BT474 and AU565 cells showed that the accrual of basal autophagosomes can give rise to TRAIL resistance by sequestering the TRAIL-R1 and TRAIL-R2 population from cell surface to cell interior and the proposed theory has been verified in MDA-MB-231 (Di et al., 2013). Intriguingly, both TSA and Zeb were shown to induce autophagy (He et al., 2014; Yang et al., 2013) which can potentially be the source of basal autophagosomes accumulation in this case. Therefore, despite TSA being able to upregulate TRAIL-R1 and TRAIL-R2, the concurrent accretion of autophagosomes through its autophagy induction might have potentially withdrawn the TRAIL-R1 and TRAIL-R2 from their active, surface localization, thereby causing the deteriorated TRAIL-mediated apoptosis signal. 
A.

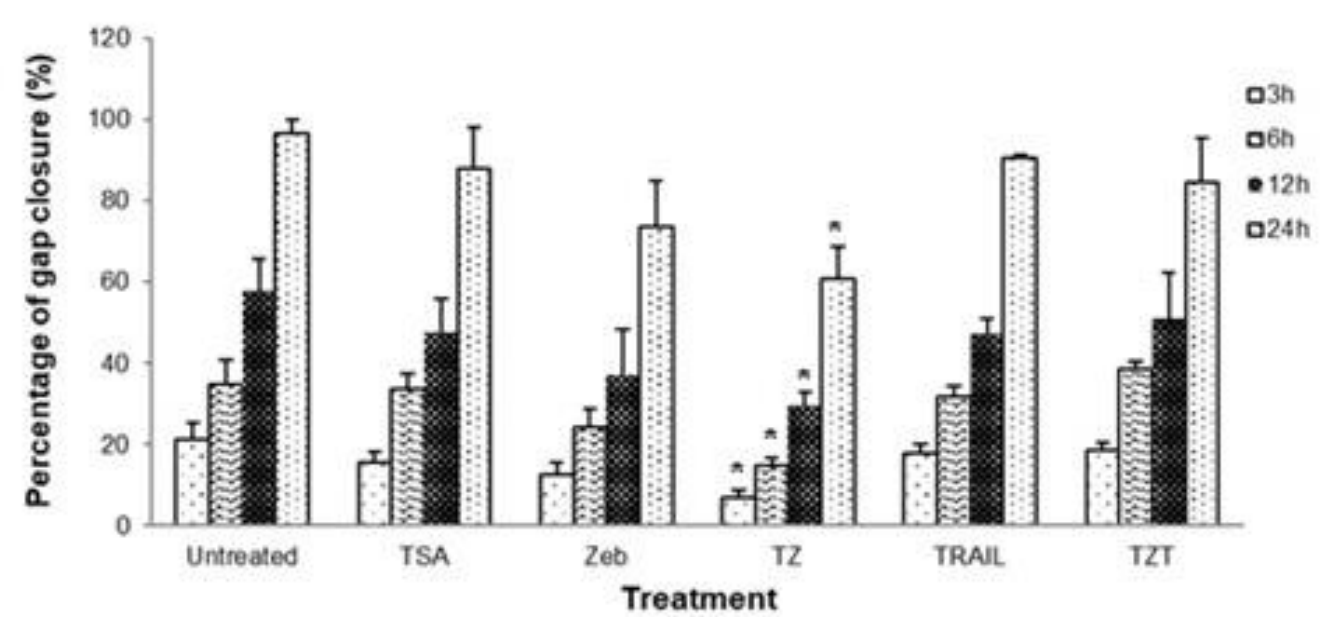

B.
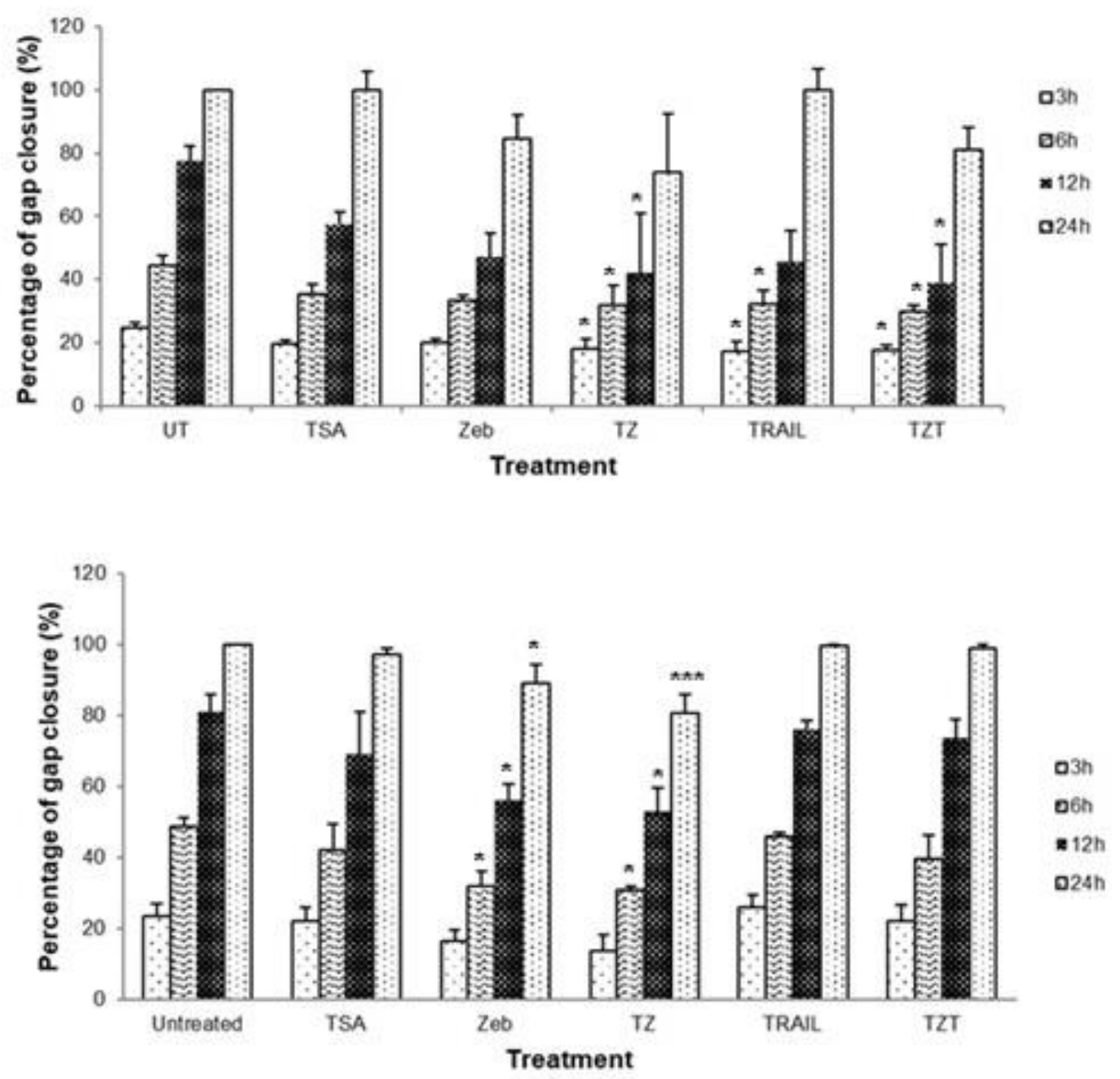

Figure 4. The percentages of gap closure at the respective time points of 3, 6, 12 and $24 \mathrm{~h}$ post-treatment in (A) MDA-MB-231, (B) 231-EV and (C) 231-EGFP are presented above. Error bars represent SEM from three independent experiments. ${ }^{*}(\mathrm{p}<0.05)$ and $* * *(\mathrm{p}<0.001)$ are significant and very significant differences from the untreated control, respectively. 


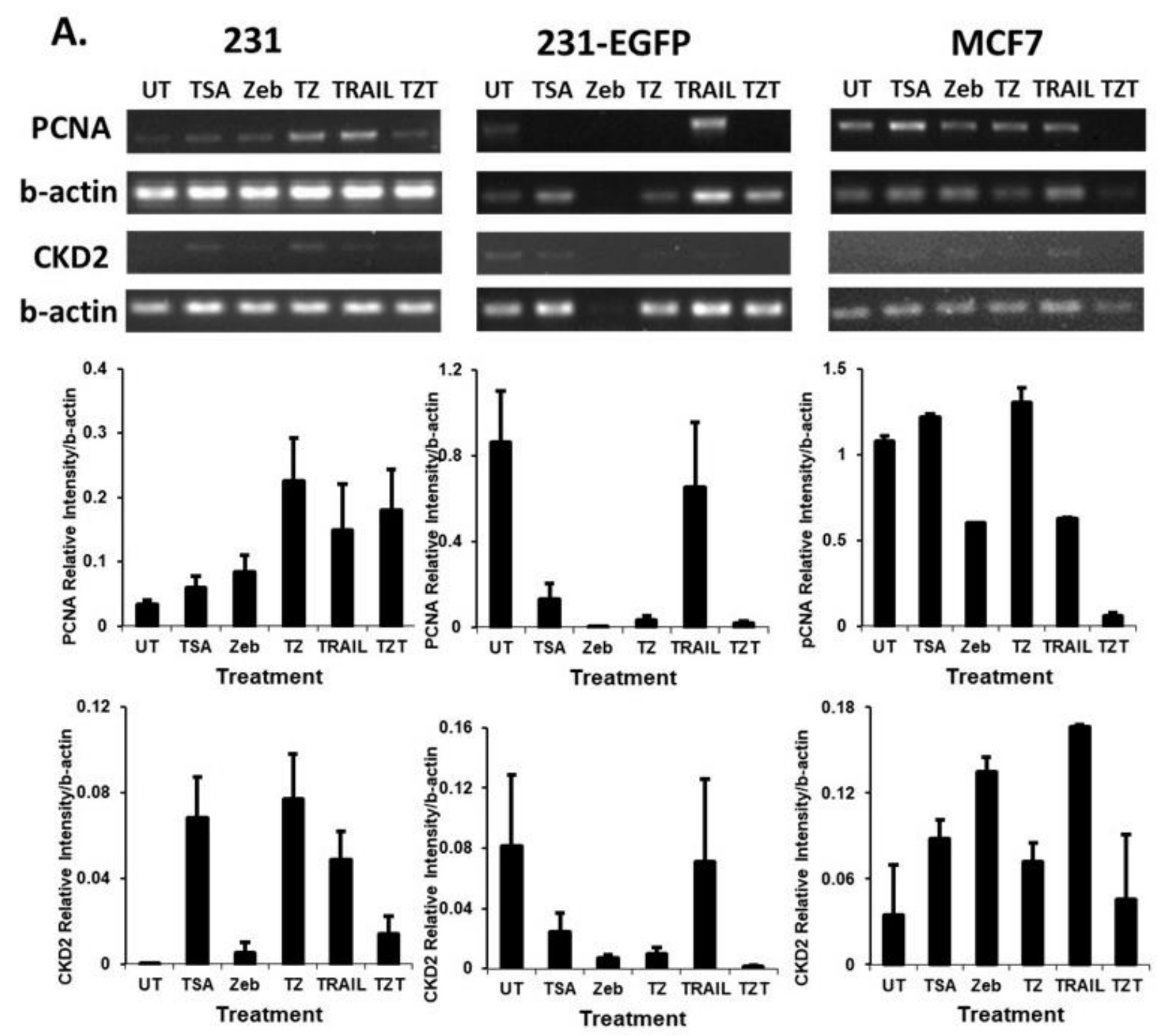

Figure 5. Total RNA extraction and RT-PCR on proliferating cell nuclear antigen (PCNA) and cyclindependent kinase 2 (CDK2) and matrix metalloproteinase 9 (MMP9). (A) MDA-MB-231 (231), geneticin selected MDA-MB-231 transfected with E-cadherin-GFP plasmid (231-EGFP) as well as MCF-7 were extracted its total RNA for untreated control (UT), TSA, Zeb, TZ, TRAIL and TZT using the RNeasy Mini Kit. The total RNA was DNase I treated and then converted to cDNA prior to PCR amplification using primers specific to PCNA and CDK2. (B) 231 and 231-EGFP were extracted its total RNA and processed as aforementioned prior to PCR amplification using primers specific to MMP9 for the treatment groups stated above. Loading amount was normalized using the housekeeping gene, beta-actin. The respective band intensity was quantified using the ImageJ software.

In contrast, with the E-cadherin re-expression, growth inhibition was induced significant $(\mathrm{P}<0.05)$ and very significant $(\mathrm{P}<0.001)$ for 231 EGFP treated with TRAIL and TZT, respectively (Figure 2). In the E-cadherin-expressing MCF-7, TZT reduced its cell viability to $66.13 \%$ which is similar to the reduction in 231-EGFP at $62.12 \%$ (Figure 2). This could potentially be explained by CDH1 interaction with the TRAIL receptors,
TRAIL-R1 and TRAIL-R2. Lu et al. (2014) have provided evidence that the interaction between $\mathrm{E}$ cadherin with TRAIL-ligated TRAIL-R1 and TRAIL-R2 on the plasma membrane, maintains the localization of the cell surface receptors and also links them to the cytoskeleton via its association with $\alpha$-actin. This therefore enhances the death-inducing silencing complex (DISC) assembly, caspase activation and subsequent 
apoptosis execution. With respect to the epigenetic drugs, the sub-toxic $\mathrm{IC}_{25}$ might be too low to induce appreciable growth inhibition on MDA-MB-231 cells with only $24 \mathrm{~h}$ of TZ treatment. However, with $C D H 1$ re-expressed, $\mathrm{CDH} 1$ with its known function as beta-catenin negative regulator might have complemented TSA and Zeb in giving rise to the significant growth inhibition in 231-EGFP (Figure 2) by negatively regulating the proliferative Wntsignaling pathway (Hulsken et al., 1994). Our finding is in agreement with the postulation that E-cadherin expression serves to enhance TRAILmediated apoptosis and the effect is more evident with the additional mechanisms of TRAIL resistance reversal via the administration of the epigenetic drugs, TSA and Zeb prior to TRAIL treatment.

The growth inhibitory effect of $24 \mathrm{~h}$ TZT treatment imposed on MDA-MB-231 reexpressed with $\mathrm{CDH} 1$ has guided us to perform the cell cycle analysis on the treated MDA-MB231, 231-EV and 231-EGFP at the time point of $24 \mathrm{~h}$. Despite the cell viability reduction was not significant for TZT-treated MDA-MB-231 (Figure 2), the TZT treatment for $24 \mathrm{~h}$ has arrested the cells very significantly $(\mathrm{P}<0.01)$ at G1/G0 phase $(57.8 \%)$ as compared to the untreated control and all other treatment groups (Figure 3). This result was in line with the low CDK2 expression (0.01) in MDA-MB-231 treated with TZT in RT-PCR (Figure 5A). Studies have shown that tumour cells, including breast cancer, induced with $G_{1}$ cell cycle arrest are more sensitized towards TRAIL-apoptosis inducing effect (Florean et al., 2016; Lu et al., 2005; Quast et al., 2015). Besides, literatures also reported that the epigenetic drugs, TSA and Zeb used in this study have induced cell cycle arrest in various neoplastic cells including breast cancer (Billam et al., 2010; Damaskos et al., 2017; Hrgovic et al., 2016). Our result is in agreement with these reports as both TSA and TZ treatments have significantly $(P<0.05)$ increased $G_{0} / G_{1}$ arrest in MDA-MB-231 comparing to the untreated cells (Figure 3). Zeb (Cheng et al., 2004) and TSA (Hrgovic et al., 2016) have also been reported to induce p21 expression which can bind to PCNA and arrest the DNA replication following DNA damage. In this regard, our finding that Zeb and TSA have largely suppressed PCNA mRNA expression (Figure 5A) concurs with the notion that these growth-inhibitory effects stem from the p21 DNA damage response pathway. On the other hand, our data showed that TZT induced either significant $(p<0.05)$ or very significant $(\mathrm{p}<0001) \mathrm{G}_{\mathrm{o}} / \mathrm{G}_{1}$ arrest in MDA-MB-231, 231 EGFP and MCF-7 (Figure 3), in line with the low CDK2 expression in these cell lines (Figure 5A). This is in concordance with the finding that $G_{o} / G_{1}$ arrest concurs with the reduction of CDK2 expression in MDA-MB-231 (Murad et al., 2016).

Therefore, it is hypothesized that the lack of cell viability reduction in MDA-MB-231 treated by TRAIL and TZT for $24 \mathrm{~h}$ (Figure 2) is explainable by the cell cycle arrest induced from the first $24 \mathrm{~h}$ of the treatment. This is a promising finding as TRAIL can be developed to target against the resting, non-proliferative tumour cells which are usually recalcitrant towards treatment and can stimulate relapse after an extended period of time (Ehrhardt et al., 2015). Since MDA-MB231 is highly proliferative, it is postulated that the efficiency of the prior treatment with TSA and Zeb followed by TRAIL in this study can be enhanced by prolonging the TSA and Zeb prior treatment to $24 \mathrm{~h}$, allowing sufficient time for the induction of cell cycle arrest prior to TRAIL treatment for the subsequent $24 \mathrm{~h}$.

On the other hand, 231-EGFP cells showed a consistent increase in arrest at $G_{0} / G_{1}$ across all treatment groups while for MCF-7 treated with TZT, the cell cycle arrest was induced significantly at $\mathrm{G}_{0} / \mathrm{G}_{1}$ phase (Figure 3). These results were in accordance to the lowest CDK2 expression of 0.0013 and 0.045 (Figure 5A) in 231-EGFP and MCF-7, respectively, treated with TZT. This can be explained by the increased E-cadherin expression which has inactivated the epidermal growth factor-receptor mitotic pathway (St Croix et al., 1998) and concurrently induced cell cycle arrest at $\mathrm{G}_{0} / \mathrm{G}_{1}$ phase by upregulating $\mathrm{cdk}$ inhibitor, $\mathrm{p} 27^{\mathrm{KIP} 1}$ and the suppressing cyclin ECdk2 complex activity (Wong et al., 2018). However, only TZT treatment significantly $(\mathrm{P}<0.05)$ arrested 231-EGFP cells in the $\mathrm{G}_{0} / \mathrm{G}_{1}$ phase $(74 \%)$ (Figure 3). This is in agreement with the finding that all treatment groups have downregulated CDK2 expression while its expression was largely suppressed by Zeb and TZT treatments (Figure 5A). Both PCNA and 
CDK2 expressions have also been suppressed by TZT treatment in MCF-7 (Figure 5A). The suppression of PCNA and CDK2 was in concordance with the reduction of cell viability $(66.13 \%)$ (Figure 2) and significant $(\mathrm{P}<0.05)$ induction of $G_{0} / G_{1}$ arrest $(83.1 \%$ ) (Figure 3 ) in MCF-7 treated with TZT for 24 hours. Moreover, TZT has induced $16.4 \%$ more $\mathrm{G}_{0} / \mathrm{G}_{1}$ arrest in 231-EGFP cells with $C D H 1$ re-expression than that induced in MDA-MB-231 with basal or no Ecadherin expression (Figure 3), further proving the enhanced anti-proliferative function of TRAIL with the supplementation of TSA and Zeb as well as with E-cadherin expression.

In term of cell migratory effect, Zeb worked effectively (Figure 4C) to reduce the cell migration to $89.1 \%(\mathrm{P}<0.05)$ and this is corroborated by the downregulation of MMP9 by Zeb in 231-EGFP (Figure 5B). In the control 231-EV cells without CDH1 expression, both TRAIL and TZT treatment groups significantly reduced cell migration rate compared to the untreated control as early as $12 \mathrm{~h}$ post-treatment (Figure 4B). However, the cells regained their initial migration rate from $12 \mathrm{~h}$ to $24 \mathrm{~h}$ post-wounding as the migration rate is similar across untreated and all treatment groups at $24 \mathrm{~h}$ post-wounding. This suggests that both TRAIL and TZT treatments were effective in reducing the migration rate at the initial stage post-treatment but the effect was temporary. This result is reasonable as TRAIL anti-neoplastic action mainly stems from apoptosis induction. However, Wang et al. (2013) have suggested anti-invasiveness potential of TRAIL by their group's observation that TRAIL suppressed a key player in MDA-MB-231 cells invasiveness, CXCR4 via the upregulation of miR-146a by NF-xB signalling pathway. Our result is in agreement with Wang et al. (2013) as this group has also observed TRAIL-induced reduction in cell migration rate within the postwounding duration of $18 \mathrm{~h}$.

Notwithstanding the decline in migration rate induced by TRAIL treatment in the early postwounding hours, the majority of the literature still supports a pro-invasiveness role played by TRAIL via the same $\mathrm{NF}-x \mathrm{~B}$ signalling pathway (Azijli et al., 2013). TRAIL-R2 seems to be the key receptor that cancer cells like breast cancer (Fritsche et al., 2015) and non-small cell lung cancer (Azijli et al., 2012) harness in the event of TRAIL-induced cellular invasiveness. Moreover, with the literatures backing that E-cadherin expression was associated with the increase in invasiveness and metastasis of cancers (Chao et al., 2010; Chao et al., 2012; Chen et al., 2015), both TRAIL and TZT treatment could not reduce the migration rate of 231-EGFP cells to a significant extent, even at 12 h post-wounding (Figure 4C). Only Zeb- and TZtreated 231-EGFP (Figure 4C) as well as TZtreated MDA-MB-231 (Figure 4A) showed significant reduction in migration rate up till the $24 \mathrm{~h}$ time point and this is corroborated by their inhibitory effect on cell migration reported in other instances (Zhou et al., 2012; Han et al., 2014) as well as MMP9 downregulation by Zeb in 231 EGFP (Figure 5B). Moreover, epigenetic data from literature have also suggested that the multilayered epigenetic regulation of MMPs, tissue inhibitors of MMPs and collagens serve as a trove of promising epigenetic drug targets in the anticancer field (Chernov and Strongin, 2011).

\section{CONCLUSION}

Our study shows a promising potential of Ecadherin expression in boosting the efficacy of epigenetic drugs, TSA and Zeb sensitization of human breast adenocarcinoma MDA-MB-231 cells towards TRAIL anti-cancer effects which include growth inhibition and $\mathrm{G}_{0} / \mathrm{G}_{1}$ cell cycle arrest by the TZT treatment. The anti-cancer effects were shown to be mediated by the suppression of PCNA and CDK2 expressions upon receiving the TZT treatment alongside Ecadherin expression. Further apoptosis assessment and its underlying molecular mechanisms on the feasibility of E-cadherin to serve as a biomarker in TZT treatment efficacy in breast cancer is warranted to validate the potential of E-cadherin as biomarker for TRAIL treatment efficacy in the invasive TNBC.

\section{ACKNOWLEDGEMENTS}

The authors would like to thank the Ministry of Education Malaysia Fundamental Research Grant 
Scheme (FRGS/1/2016/STG05/UNIM/03/1) for supporting this work.

\section{REFERENCES}

Agarwal, G., Pradeep, P. V., Aggarwal, V, Yip, C. H. \& Cheung, P. S. Y. 2007. Spectrum of breast cancer in Asian women. World Journal of Surgery 31(5): 1031-1040.

Ashkenazi, A. 2008. Targeting the extrinsic apoptosis pathway in cancer. Cytokine \& Growth Factor Reviens 19(3-4): 325-331.

Ashkenazi, A., Pai, R. C., Fong, S., Leung, S., Lawrence, D. A., Marsters, S. A., Blackie, C., Chang, L., McMurtrey, A. E., Hebert, A., DeForge, L., Koumenis, I. L., Lewis, D., Harris, L., Bussiere, J., Koeppen, H., Shahrokh, Z. \& Schwall, R. H. 1999. Safety and antitumor activity of recombinant soluble Apo2 ligand. Journal of Clinical Investigation 104(2): $155-162$.

Azijli, K., Weyhenmeyer, B., Peters, G. J., de Jong, S. \& Kruyt, F.A.E. 2013. Non-canonical kinase signaling by the death ligand TRAIL in cancer cells: discord in the death receptor family. Cell Death Differentiation 20(7): 858-868.

Azijli, K., Yuvaraj, S., Peppelenbosch, M. P., Würdinger, T., Dekker, H., Joore, J., van Dijk, E., Quax, W. J., Peters, G. J., de Jong, S. \& Kruyt, F. A. 2012. Kinome profiling of non-canonical TRAIL signaling reveals RIP1-Src-STAT3dependent invasion in resistant non-small cell lung cancer cells. Journal of Cell Science 125(Pt 19): 4651-4661.

Azubuike, S. O., Muirhead, C., Hayes, L. \& McNally, R. 2018. Rising global burden of breast cancer: the case of subSaharan Africa (with emphasis on Nigeria) and implications for regional development: a review. World Journal of Surgical Oncology 16: 63.

Bae, G. Y., Choi, S. J., Lee, J. S., Jo, J., Lee, J., Kim, J. \& Cha, H.J. 2013. Loss of E-cadherin activates EGFR-MEK/ERK signaling, which promotes invasion via the ZEB1/MMP2 axis in non-small cell lung cancer. Oncotarget 4(12): 2512 2522.

Bangert, A., Cristofanon, S., Eckhardt, I., Abhari, B. A., Kolodziej, S. Häcker, S., Vellanki, S. H. K., Lausen, L. Debatin, K.-M. \& Fulda, S. 2012. Histone deacetylase inhibitors sensitize glioblastoma cells to TRAIL-induced apoptosis by c-mycmediated downregulation of cFLIP. Oncogene 31(44): 46774688.

Billam, M., Sobolewski, M. D. \& Davidson, N. E. 2010. Effects of a novel DNA methyltransferase inhibitor zebularine on human breast cancer cells. Breast Cancer Research and Treatment 120(3): 581-592.

Butler, L. M., Liapis, V., Bouralexis, S., Welldon, K., Hay, S., Thai L, M., Labrinidis, A. Tilley, W. D., Findlay, D. M. \& Evdokiou, A. 2006. The histone deacetylase inhibitor, suberoylanilide hydroxamic acid, overcomes resistance of human breast cancer cells to Apo2L/TRAIL. International Journal of Cancer 119(4): 944-954.

Bray, F., Ferlay, J., Soerjomataram, I., Siegel, R. L., Torre, L. A. \& Jemal, A. 2018. Global cancer statistics 2018: GLOBOCAN estimates of incidence and mortality worldwide for 36 cancers in 185 countries. CA: A Cancer Journal for Clinicians 68(6): 394-424.

Chao, Y. L., Shepard, C. R. \& Wells, A. 2010. Breast carcinoma cells re-express E-cadherin during mesenchymal to epithelial reverting transition. Molecular Cancer 9: 179.

Chao Y., Wu, Q., Acquafondata, M., Dhir, R. \& Wells, A. 2012. Partial mesenchymal to epithelial reverting transition in breast and prostate cancer metastases. Cancer Microenvironment 5(1): 19-28.
Chen L, Jian W, Lu L, Zheng, L., Yu, Z. \& Zhou, D. 2015. Elevated expression of E-cadherin in primary breast cancer and its corresponding metastatic lymph node. International Journal of Clinical and Experimental Medicine 8(7): 1175211758.

Cheng, J. C., Yoo, C. B., Weisenberger, D. J., Chuang, J., Wozniak, C., Liang, G., Marquez, V. E., Greer, S., Orntoft, T. F., Thykjaer, T. \& Jones, P. A. 2004. Preferential response of cancer cells to zebularine. Cancer Cell 6(2): 151-158.

Chernov, A. V. \& Strongin, A. Y. 2011 Epigenetic regulation of matrix metalloproteinases and their collagen substrates in cancer. Biomolecular Concepts 2(3): 135-147.

Comşa, Ş., Cîmpean, A. M. \& Raica, M. 2015. The story of MCF7 breast cancer cell line: 40 years of experience in research. Anticancer Research 35(6): 3147-3154.

Damaskos, C., Garmpis, N., Valsami, S., Kontos, M., Spartalis, E., Kalampokas, T., Kalampokas, E., Athanasiou, A., Moris, D., Daskalopoulou, A., Davakis, S., Tsourouflis, G., Kontzoglou, K, Perrea, D., Nikiteas, N. \& Dimitroulis, D. 2017. Histone deacetylase inhibitors: An attractive therapeutic strategy against breast cancer. Anticancer Research 37(1): 35-46.

Di, X., Zhang, G., Zhang, Y., Takeda, K., Rivera Rosado, L. A. \& Zhang, B. 2013. Accumulation of autophagosomes in breast cancer cells induces TRAIL resistance through downregulation of surface expression of death receptors 4 and 5. Oncotarget 4(9): 1349-1364.

Dimberg, L. Y., Anderson, C. K., Camidge, R., Behbakht, K., Thorburn, A. \& Ford, H.L. 2013. On the TRAIL to successful cancer therapy? Predicting and counteracting resistance against TRAIL-based therapeutics. Oncogene 32(11): 1341-1350.

Ehrhardt, H., Alves, C. C., Wachter, F. \& Jeremias, I. 2015. TRAIL preferentially affects cell cycle-arrested tumor cells including stem- and progenitor cells from patients with acute lymphoblastic leukemia. Blood 120: 1879.

Florean, C., Schnekenbruger, M., Lee, J.-Y., Kim, K. R., Mazumder, A., Song, S., Kim J.-M., Grandjenette, C., Kim, J.-G., Yoon, A.-Y., Dicato, M., Kim, K.-W., Christov, C. Han, B.-W., Proksch, P \& Diederich, M. 2016. Discovery and characterization of Isofistularin-3, a marine brominated alkaloid, as a new DNA demethylating agent inducing cell cycle arrest and sensitization to TRAIL in cancer cells. Oncotarget 7(17): 24027-24049.

Fritsche, H., Heilmann, T., Tower, R.J., Hauser, C., von Au, A., El-Sheikh, D.,.Campbell, G. M., Alp, G., Schewe, D., Hubner, S., Tiwari, S., Kownatzki, D., Boretius, S., Adam, D., Jonat, W., Backer, T., Gluer, C. C., Zoller, M., Kalthoff, H., Schem, C. \& Trauzold, A. 2015. TRAIL-R2 promotes skeletal metastasis in a breast cancer xenograft mouse model. Oncotarget 6(11): 9502-9516.

Fulda, S. 2015. Safety and tolerability of TRAIL receptor agonists in cancer treatment. European Journal of Clinical Pharmacology 71(5): 525-527.

Han, R. F., Li, K., Yang, Z. S., Chen, Z. G. \& Yang, W. C. 2014. Trichostatin A induces mesenchymal-like morphological change and gene expression but inhibits migration and colony formation in human cancer cells. Molecular Medicine Reports 10(6): 3211-3216.

He, G., Wang, Y., Pan, X. \& Zhang, B. 2014. Inhibition of autophagy induced by TSA sensitizes colon cancer cell to radiation. Tumor Biology 35(2): 1003-1011.

Herbst, R. S., Eckhardt, S. G., Kurzrock, R., Ebbinghaus, S., O'Dwyer, P.J., Gordon, M.S., Novotny, W., Goldwasser, M. A., Tohnya, T. M., Lum, B. L., Ashkenazi, A., Jubb, A. M. \& Mendelson, D. S. 2010. Phase I dose-escalation study of recombinant human Apo2L/TRAIL, a dual proapoptotic receptor agonist, in patients with advanced 
cancer. Journal of Clinical Oncology 28(17): 2839-2846.

Hrgovic, I., Doll, M., Kleemann, J., Wang, X. F.; Zoeller, N.; Pinter, A., Kippenberger, S., Kaufmann R. \& Meissner, M. 2016. The histone deacetylase inhibitor trichostatin a decreases lymphangiogenesis by inducing apoptosis and cell cycle arrest via p21-dependent pathways. BMC Cancer 16(1):763

Hulsken, J., Birchmeier, W. \& Behrens, J. 1994. E-cadherin and APC compete for the interaction with beta-catenin and the cytoskeleton. Journal of Cell Biology 127(6 Pt2): 2061-2069.

Jonkman, J. E., Cathcart, J. A., Xu, F., Bartolini, M. E.; Amon, J. E., Stevens, K. M. \& Colarusso, P. 2014. An introduction to the wound healing assay using live-cell microscopy. Cell Adhesion and Migration 8(5): 440-451.

Kelley, S. K. \& Ashkenazi, A. 2004. Targeting death receptors in cancer with Apo2L/TRAIL. Current Opinion in Pharmacology 4(4): 333-339.

Kim, Y. H., Park, J. W., Lee, J. Y., Lee, J. Y. \& Kwon, T. K. 2004. Sodium butyrate sensitizes TRAIL-mediated apoptosis by induction of transcription from the DR5 gene promoter through Sp1 sites in colon cancer cells. Carcinogenesis 25(10): 1813-1820.

Kohler, B. A., Sherman, R. L., Howlader, N., Jemal, A.; Ryerson, A. B., Henry, K. A., Boscoe, F. P., Cronin, K. A., Lake, A., Noone, A.-M., Henley, S. J., Eheman, C. R., Anderson, R. N. \& Penberthy, L. 2015. Annual Report to the nation on the status of cancer, 1975-2011, featuring incidence of breast cancer subtypes by race/ethnicity, poverty, and state. Journal of the National Cancer Institute 107(6): djv048.

Kowalski, P. J., Rubin, M. A. \& Kleer, C. G. 2003. E-cadherin expression in primary carcinomas of the breast and its distant metastases. Breast Cancer Research 5(6): R217-R222.

Lauricella, M., Ciraolo, A., Carlisi, D. Vento, R. \& Tesoriere, G. 2012. SAHA/TRAIL combination induces detachment and anoikis of MDA-MB231 and MCF-7 breast cancer cells. Biochimie 94(2): 287-299.

Leong, S. P., Shen, Z.-Z, Liu, T.-J., Agarwal, G., Tajima, T., Paik, N.-S., Sandelin, K., Derossis, A., Cody, H \& Foulkes, W. D. 2010. Is breast cancer the same disease in Asian and Western countries? World Journal of Sungery 34(10): 23082324.

Lombaerts, M., van Wezel, T., Philippo, K., Dierssen, J. W., Zimmerman, R. M., Oosting, J., van Eijk, R. Eilers, P. H., van de Water, B., Cornelisse, C. J. \& Cleton-Jansen, A.-M. 2006. E-cadherin transcriptional downregulation by promoter methylation but not mutation is related to epithelial-to-mesenchymal transition in breast cancer cell lines. British Journal of Cancer 94(5): 661-671.

Li, H., Qiu, Z., Li, F. \& Wang, C. 2017. The relationship between MMP-2 and MMP-9 expression levels with breast cancer incidence and prognosis. Oncology Letters 14(5): 5865-5870.

Lu, M., Kwan, T., Yu, C., Chen, F., Freedman, B., Schafer, J. M., Lee, E.-J., Jameson, J. L., Jordan, V. C. \& Cryns, V. L. 2005. Peroxisome proliferator-activated receptor gamma agonists promote TRAIL-induced apoptosis by reducing survivin levels via cyclin D3 repression and cell cycle arrest. The Journal of Biological Chemistry 280(8): 6742-6751.

Lu, M., Marsters, S., Ye, X., Luis, E., Gonzalez, L. \& Ashkenazi, A. 2014. E-cadherin couples death receptors to the cytoskeleton to regulate apoptosis. Molecular Cell 54(6): 987998.

Masuda, H., Baggerly, K. A., Wang, Y., Zhang, Y., GonzalezAngulo, A. M., Meric-Bernstam, F., Valero, V., Lehmann, B. D., Pietenpol, J. A., Hortobagyi, G. N., Symmans, W. F. \& Ueno, N. T. 2013. Differential response to neoadjuvant chemotherapy among 7 triple-negative breast cancer molecular subtypes. Clinical Cancer Research 19(19): 55335540 .
Moriwaki, K., Narisada, M., Imai, T., Shinzaki, S. \& Miyoshi, E. 2010. The effect of epigenetic regulation of fucosylation on TRAIL-induced apoptosis. Glycoconjugate Journal 27(7-9): 649-659.

Moriwaki, K., Noda, K., Furukawa, Y., Ohshima, K., Uchiyama, A., Nakagawa, T., Taniguchi, N., Daigo, Y., Nakamura, Y., Hayashi, N \& Miyoshi, E. 2009. Deficiency of GMDS leads to escape from NK cell-mediated tumor surveillance through modulation of TRAIL signaling. Gastroenterology 137(1): 188-198.e1982.

Murad, H, Hawat, M,. Ekhtiar, A., AlJapawe, A., Abbas, A., Darwish, H. Sbenati, O. \& Ghannam, A. 2016. Induction of G1-phase cell cycle arrest and apoptosis pathway in MDA-MB-231 human breast cancer cells by sulfated polysaccharide extract from Laurencia papillosa. Cancer Cell International 16: 39 .

Nakamura, K., Aizawa, K., Nakabayashi, K., Kato, N., Yamauchi, J., Hata, K. \& Tanonue, A. 2013. DNA methyltransferase inhibitor zebularine inhibits human hepatic carcinoma cells proliferation and induces apoptosis. PLoS One 8(1): e54036.

Onder, T. T., Gupta, P. B., Mani, S. A., Yang, J., Lander, E. S. \& Weinberg, R.A. 2008. Loss of E-cadherin promotes metastasis via multiple downstream transcriptional pathways. Cancer Research 68(10): 3645-3654.

Perrot-Applanat, M. \& Di Benedetto, M. 2012. Autocrine functions of VEGF in breast tumor cells: adhesion, survival, migration and invasion. Cell Adhesion \& Migration 6(6): 547-553.

Portanova, P., Notaro, A., Pellerito, O., Sabella, S., Giuliano, M. \& Calvaruso, G. 2013. Notch inhibition restores TRAILmediated apoptosis via AP1-dependent upregulation of DR4 and DR5 TRAIL receptors in MDA-MB-231 breast cancer cells. International Journal of Oncology 43(1): 121-130.

Quast, S. A., Steinhorst, K., Plötz, M. \& Eberle, J. 2015. Sensitization of melanoma cells for death ligand TRAIL Is based on cell cycle arrest, ROS production, and activation of proapoptotic Bcl-2 proteins. Journal of Investigative Dermatology 135(11): 2794-2804.

Scully, O. J., Bay, B. H., Yip, G. \& Yu, Y. 2012. Breast cancer metastasis. Cancer Genomics and Proteomics 9(5): 311-320.

Shargh, S. A., Sakizli, M., Khalaj, V., Movafagh, A., Yazdi, H., Hagigatjou, E., Sayad, A., Mansouri, N., MortazaviTabatabaei, S. A. \& Khorshid, H. R. K. 2014. Downregulation of E-cadherin expression in breast cancer by promoter hypermethylation and its relation with progression and prognosis of tumor. Medical Oncology 31(11): 250.

Shin, H.-R., Bonjol, M., Joubert, C., Hery, C., Haukka, J., Autier, P., Nishino, Y., Sobue, M., Chen, C.-J., You, S.-L., Ahn, S.H., Jung, K. W., Law, S. C.-K., Mang, O. \& Chia, K.-S. 2010. Secular trends in breast cancer mortality in five East Asian populations: Hong Kong, Japan, Korea, Singapore and Taiwan. Cancer Science 101(5): 1241-1246.

Singh, T. R., Shankar, S. \& Srivastava, R. K. 2005. HDAC inhibitors enhance the apoptosis-inducing potential of TRAIL in breast carcinoma. Oncogene 24(29): 4609-4623.

Srivastava, R. K., Kurzrock, R. \& Shankar, S. 2010. MS-275 Sensitizes TRAIL-resistant breast cancer cells, inhibits angiogenesis and metastasis, and reverses epithelialmesenchymal transition in vivo. Molecular Cancer Therapeutics 9(12): 3254-3266.

St Croix, B., Sheehan, C., Rak, J. W., Flørenes, V.A.; Slingerland, J. M. \& Kerbel, R. S. 1998. E-Cadherin-dependent growth suppression is mediated by the cyclin-dependent kinase inhibitor p27(KIP1). Journal of Cell Biology 142(2): 557-571.

Stuckey, D. W. \& Shah, K. 2013. TRAIL on trial: preclinical advances in cancer therapy. Trends in Molecular Medicine 19(11): 685-694. 
Sweeney, K. J., Sarcevic, B., Sutherland, R. L. \& Musgrove, E. A. 1997. Cyclin D2 activates Cdk2 in preference to Cdk4 in human breast epithelial cells. Oncogene 14(11): 1329-1340.

Twomey, J. D., Kim, S. R., Zhao, L., Bozza, W. P. \& Zhang, B. 2015. Spatial dynamics of TRAIL death receptors in cancer cells. Drug Resistance Updates 19: 13-21.

van Roy, F. \& Berx, G. 2008. The cell-cell adhesion molecule Ecadherin. Cellular and Molecular Life Sciences 65(23): 37563788.

Wagner, K. W., Punnoose, E. A., Januario, T., Lawrence, D.A., Pitti, R.M.; Lancaster, K., Lee, D., von Goetz, M., Yee, S. F., Totpal, K., Huw, L., Katta, V., Cavet, G., Hymowitz, S. G., Amber, L. \& Ashkenazi, A. 2007. Death-receptor Oglycosylation controls tumor-cell sensitivity to the proapoptotic ligand Apo2L/TRAIL. Nature Medicine 13(9): 1070-1077.

Wang, D., Liu, D., Gao, J., Liu, M., Liu, S., Jiang, M., Liu, Y. \& Zheng, D. 2013. TRAIL-induced miR-146a expression suppresses CXCR4-mediated human breast cancer migration. The FEBS Journal 280(14): 3340-3353.

Wang, H., Xu, C., Kong, X., Li, X., Kong, X., Wang, Y., Ding, X. \& Yang Q. 2014. Trail resistance induces epithelialmesenchymal transition and enhances invasiveness by suppressing PTEN via miR-221 in breast cancer. PLoS One 9(6): e99067.

Wong, S. H. M., Fang, C. M., Chuah, L. H., Leong, C.O. \& Ngai, S. C. 2018. E-cadherin: Its dysregulation in carcinogenesis and clinical implications. Critical Reviews in Oncology/Hematology 121: 11-22.

Yan, S., Qu, X., Xu, C., Zhu, Z., Zhang, L.; Xu, L., Song, N., Teng, Y \& Liu, Y. 2012. Down-regulation of Cbl-b by bufalin results in up-regulation of DR4/DR5 and sensitization of TRAIL-induced apoptosis in breast cancer cells. Journal of Cancer Research and Clinical Oncology 138(8): 1279-1289.

Yang, P. M., Lin, Y.-T., Shun, C.-T., Lin, S.-H., Wei, T.-T., Chuang, S.-H., Wu, M.-S. \& Chen, C.-C. 2013. Zebularine inhibits tumorigenesis and stemness of colorectal cancer via p53dependent endoplasmic reticulum stress. Scientific Reports 3 : 3219.

Yoshida, T., Zhang, Y., Rivera Rosado, L. A. \& Zhang, B. 2009. Repeated treatment with subtoxic doses of TRAIL induces resistance to apoptosis through its death receptors in MDAMB-231 breast cancer cells. Molecular Cancer Research 7(11): 1835-1844.

Youlden, D. R., Cramb, S. M., Yip, C. H. \& Baade, P. D. 2014. Incidence and mortality of female breast cancer in the AsiaPacific region. Cancer Biology \& Medicine 11(2): 101-115.

Youlden, D. R., Cramb, S. M., Dunn, N. A., Muller, J. M., Pyke, C. M. \& Baade, P. D. 2012. The descriptive epidemiology of female breast cancer: An international comparison of screening, incidence, survival and mortality. Cancer Epidemiology 36(3): 237-248.

Zhang, Y., Yoshida, T. \& Zhang, B. (2009) TRAIL induces endocytosis of its death receptors in MDA-MB-231 breast cancer cells. Cancer Biology \& Therapy 8(10): 917-922.

Zhang, Y. \& Zhang, B. 2008. TRAIL resistance of breast cancer cells is associated with constitutive endocytosis of death receptors 4 and 5. Molecular Cancer Research 6(12): 18611871.

Zhou, P., Lu, Y. \& Sun, X. H. 2012. Effects of a novel DNA methyltransferase inhibitor Zebularine on human lens epithelial cells. Molecular Vision 18: 22-28. 